\title{
Distribution and Characterization of Heavy Metal and Pollution Indices in Landfill Soil for Its Rehabilitation by Phytoremediation
}

\author{
Kraidy N'gattah Barthélémy Armel, Bolou Bi Bolou Emile*, Allou Kouassi Daniel \\ Université Félix Houphouët-Boigny, Unité de Formation et Recherche des Sciences de la Terre et des Ressources Minières, \\ Laboratoire des Sciences du Sol, de l'Eau et des Géomatériaux (LSSEG), Abidjan, Côte d'Ivoire \\ Email: *emile.bolou@univ-fhb.edu.ci
}

How to cite this paper: Armel, K. N. B., Emile, B. B. B., \& Daniel, A. K. (2022). Distribution and Characterization of Heavy Metal and Pollution Indices in Landfill Soil for Its Rehabilitation by Phytoremediation. Journal of Geoscience and Environment Protection, 10, 151-172.

https://doi.org/10.4236/gep.2022.101011

Received: August 3, 2021

Accepted: January 23, 2022

Published: January 26, 2022

Copyright $\odot 2022$ by author(s) and Scientific Research Publishing Inc. This work is licensed under the Creative Commons Attribution International License (CC BY 4.0).

http://creativecommons.org/licenses/by/4.0/ (c) (i) Open Access

\begin{abstract}
Population growth associated with urban development in African cities is a key environmental concern in development programs. Indeed, urban areas are strongly impacted by the production of municipal waste, the management of which remains problematic and is only stored in open dumps. This is the case in the city of Bonoua, a small town located $59 \mathrm{~km}$ east of Abidjan in the South Comoé region of Côte d'Ivoire. The management of municipal waste in this town is crucial because all the mineral water sources are concentrated in this town. The objective of this study is to characterize and map the distribution of trace metal elements in the largest urban landfill in the city in order to propose an efficient strategy for rehabilitation into an urban park. Soil samples were collected from the entire site (landfill and surrounding soil) and from a control site. The total content of trace metals $(\mathrm{Pb}, \mathrm{Cd}, \mathrm{Cr}$, and $\mathrm{Zn})$ in the soil was analyzed by X-ray fluorescence spectrometry (XRF). Soil pollution was evaluated through enrichment factors, geoaccumulation indices and pollution indices. The results show that the calculated geoaccumulation indices and their distribution maps indicate a pollution of the site in these elements. The values of the PI higher than the unit reveal a pollution of the site in several elements. The levels of $\mathrm{Pb}, \mathrm{Cd}, \mathrm{Cr}$ and $\mathrm{Zn}$ are higher than the levels in the upper continental crust and in the control soil. The spatial distribution shows a significant accumulation of $\mathrm{Pb}, \mathrm{Cr}$ and $\mathrm{Zn}$ on the landfill while $\mathrm{Cd}$ is concentrated in the surrounding soils. The calculated enrichment factors suggest an anthropogenic origin of the heavy metal at the study site. These results indicate polymetallic pollution by metals that can persist in the environment and affect human health.
\end{abstract}

\section{Keywords}

Municipal Landfill, Soil, Heavy Metals, Pollution, Bonoua, Ivory Coast 


\section{Introduction}

The United Nations estimated in 2019 the world population at 7.7 billion. This population would expect 9.7 billion in 2050 and about 11 billion in the year 2100 (UN, 2019). The world population growth is very unevenly distributed around earth. Indeed, the population growth will take place mainly in the countries of the South (sub-Saharan Africa and Southeast Asia). In sub-Saharan Africa countries, populations triple in just twenty years. These countries are therefore facing profound societal transformations. About, $37 \%$ of the population of African countries lived now in urban areas, and this proportion of the urban population will continue to increase to reach approximately $70 \%$ in 2100 . Côte d'Ivoire, located in West Africa, is one of these sub-Saharan Africa countries that were already $51 \%$ of its population live in cities (UN, 2019). One of direct consequences is a galloping urbanization with a high production of urban waste (domestic and industrial).

Thus, in Ivorian cities, municipalities, urban activities and industries from all over the world produce tons of waste each year that is disposed of in open municipal landfills. For example, in the district of Abidjan, waste production increased from 994,043 tons in 1998 to 1,438,779 tons in 2005 (Soro et al., 2010; N'guettia, 2010). This rapid urbanization of large cities in Côte d'Ivoire is not followed by an effective household waste (solid and liquid) management policy. Thus, open dumps remain the best option in Ivorian cities for solid waste disposal because they can accommodate huge volumes of waste and are less expensive to operate. Despite these advantages, landfills remain significant point sources of pollutants. Indeed, the waste dumped in municipal landfills is generally made up of chemicals (pharmaceuticals, batteries), metal, hospital products and household waste. They therefore contain elements that are hazardous to human health. The successive inputs of these wastes in the landfill lead to an accumulation of these elements in the landfills due to the natural biogeochemical degradation. Furthermore, in a tropical climate context with high rainfall, landfills produce leachate through the combination of decomposing waste and water percolating through the waste in the landfill (Chapelle, 2013). This leachate is the primary vector of these contaminants from the landfill to the surrounding soil. Landfill leachate usually contains inorganic macrocomponents, heavy metals, polycyclic aromatic hydrocarbons (PAHs), pesticides, etc. derived from decomposing waste (Kjeldsen et al., 2002). Among these leachate constituents, heavy metals have received global attention because they cause several negative health and environmental impacts (Kim \& Lee, 2009; Ngole \& Ekosse, 2012).

Heavy metals refer to any metallic chemical element that has a relatively high density and is toxic or poisonous at low concentrations (Fergusson, 1990). These metals are used in many human activities and are therefore contained in waste entering most landfills. The occurrence of heavy metals in landfill leachate and soils around landfill environments is widely reported (Ngole \& Ekosse, 2012; Kanmani \& Gandhimathi, 2013) and is associated with the mi- 
gration of landfill leachate. It is known that soils around landfills are usually rich in organic matter and fertile and are sometimes used for growing food crops (Kihampa et al., 2011, Guety et al., 2017) especially for vegetable production (tomatoes, cabbage, lettuce, cucumber, spinach, eggplant, etc.) (Guety et al., 2017). Vegetable production on landfill soils poses a health risk to the urban population because of the potential contamination of the trophic chain due to the transfer of pollutants from the soil to vegetables (Guety et al., 2017). Monitoring and maintaining a closed landfill for a long period has been recommended to decrease the negative impacts associated with migrating leachate from such landfills (Gerth et al., 2016). However, landfill plays an essentials economic role for communities around closed landfills. It is therefore necessary to do some actions to carry out landfill soil rehabilitations before their transformation for agricultural support. One of the cheapest methods is the use of plants to clean up these soils. The phytoremediation is a method adapted to the urban context through the creation of an urban forest ecosystem. The establishment of this urban forest ecosystem requires knowledge and characterization of the landfill sites. Thus, this study assesses heavy metal concentrations in soils around the closed landfill and aims to characterize and map the distribution of these trace metal elements in an urban landfill in order to propose an efficient rehabilitation strategy for an urban park.

\section{Materials and Methods}

\subsection{Study Site}

The study was conducted in Bonoua, town located in the southeast of Côte d'Ivoire. It is located $59 \mathrm{~km}$ from the center of Abidjan. Bonoua is located between latitudes $5^{\circ} 08^{\prime} \mathrm{N}$ and $5^{\circ} 33^{\prime} \mathrm{N}$ and longitudes $3^{\circ} 13^{\prime} \mathrm{W}$ and $3^{\circ} 51^{\prime} \mathrm{W}$ (Figure 1). It receives an average annual precipitation of about $1700 \mathrm{~mm}$ and the climate is bimodal with a long rainy season from March to July and a long dry season from December to February. The vegetation varies from open forest to dense evergreen forest. The soils are mainly hydromorphic and peaty with 10 to $45 \%$ clay but with a dominance of sand. These soils have a high erodibility and water infiltration rate (Aké, 2010). The importance of the city of Bonoua lies in the fact that all mineral water sources and new boreholes that supply the Abidjan district with drinking water are located around the city. The study site is a former landfill located in the M'Ploussoué Park, which covers 16 ha and is located southwest of Bonoua.

\subsection{Soil Sampling and Treatment}

Two zones were distinguished within the landfill, namely the landfill itself and zone with soils surrounding the landfill, and which receive the leaching water from the landfill. For the soil characterization, two soil pits were opened and described on the landfill and outside the landfill perimeter. Soil samples were then collected using a systematic $3 \mathrm{~m} \times 3 \mathrm{~m}$ square grid sampling method to cover the 


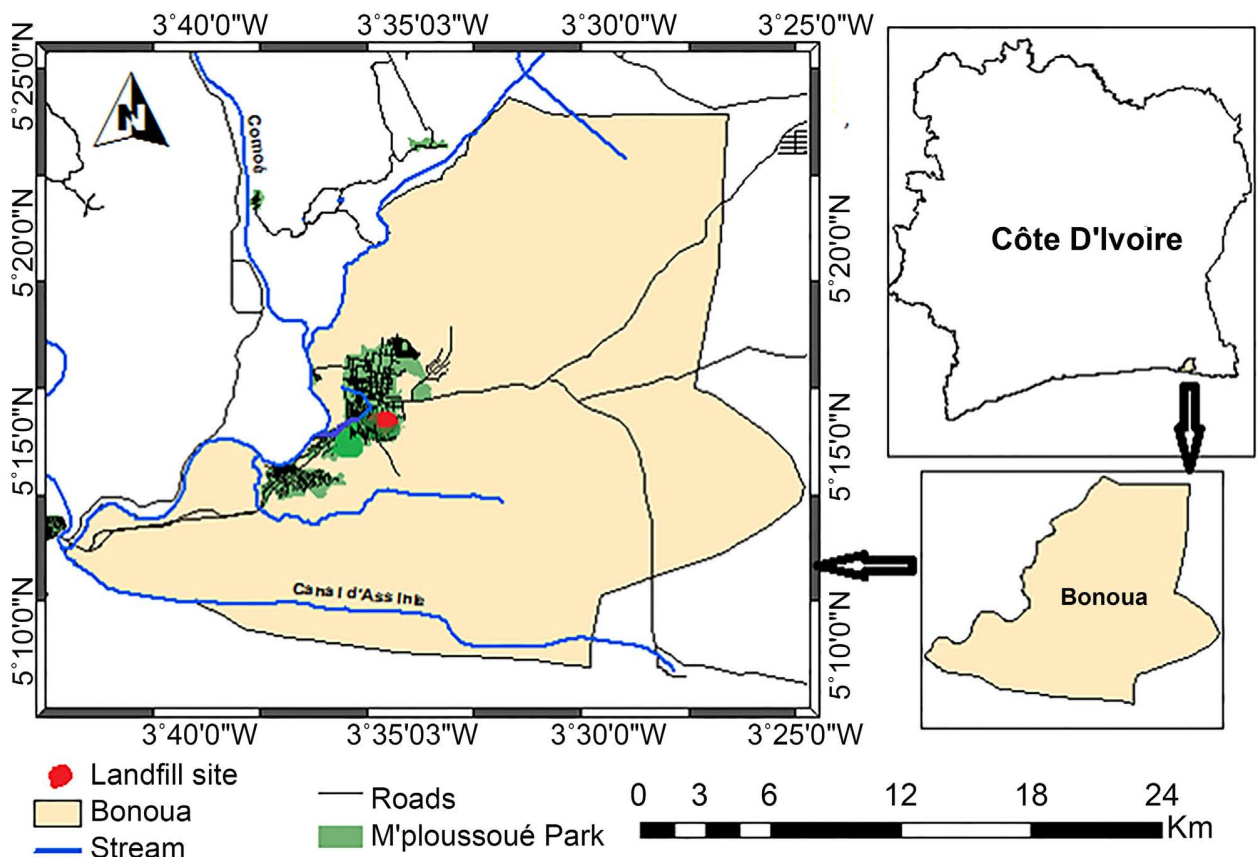

Figure 1. Location of the study zone.

entire landfill and surrounding perimeter. Soil samples were taken at each mesh node with soil auger between 0 and $20 \mathrm{~cm}$.

\subsection{Soil Analyses}

\section{Physical and Chemical Parameters}

Soil granulometry, organic matter content and cation exchange capacity (CEC) were determined according to the classical laboratory methods, namely respectively according to the NF X 31-107 standard (Granulometry 5 fractions without decarbonation) (NF ISO 10694 (dry combustion) and NF X 31-130 standard (Extraction with cobaltihexamine chloride) described by the INRAE soil analysis laboratory (Arras France). The $\mathrm{pH}_{\text {water }}$ and $\mathrm{pH}_{\mathrm{KCl}}$ of the soils were determined after suspending the air-dried soil sample in water in a $1 / 5(\mathrm{~m} / \mathrm{v})$ ratio according to the methods of NF ISO 10390 respectively.

The determination of the trace metal element content in soil samples was carried out according to two methods. The first one concerns samples without organic matter. The analysis of these samples was done using a fluorescence spectrometer $\left(\right.$ Niton ${ }^{\circledR}$ XL3t) in the Laboratory of PetroMetallogeny of the Felix Houphouët-Boigny University, Abidjan. This spectrometer offers the advantage of a non-destructive measurement of the sample to easily analyze more than 25 chemical elements. In the case of samples rich in organic matter, the analysis was performed after acid digestion by Inductively Coupled Plasma Mass Spectrometer (ICP-MS) based at the GSE laboratory of University of Paris Créteil (France).

\subsection{Evaluation of Soil Contamination in Trace Metal Elements}

The enrichment factor (EF), the geoaccumulation index (Igeo) and the pollution 
index (PI) were calculated in order to estimate the intensity of soil contamination and pollution in trace metal element. The principle is based on the comparison of measured values with reference values such as the average content of elements in the earth's crust or the limit content in the soil. These indices allow knowing the respective contribution of the anthropic and natural sources possibly present in the soils of the study site.

The enrichment factor provides the number of times an element is enriched relative to the abundance of that element in the reference material in the upper continental crust (UCC). This factor has been proposed to accurately distinguish anthropogenic inputs from natural sources and thus define the intensity of contamination (Rubio et al., 2000). The reference material used in this study is the one defined elsewhere (Okuo \& Ndiokwere, 2006) and recognized worldwide as the reference concentration in unpolluted areas. Its calculation was defined by relating the content of a contaminant element in the sample to the concentration of an element deemed relatively immobile in that sample, compared with the same ratio found in the reference material. Iron was chosen as the immobile reference element for this calculation because it occurs naturally in the study site soils and is one of the reference materials commonly used in the literature (Liu et al., 2005; Fang et al., 2006). In this study, the enrichment factor was computed as reference element and was given by:

$$
\mathrm{FE}=\frac{[\mathrm{M}]_{\text {Sample }} /[\mathrm{Fe}]_{\text {Sample }}}{[\mathrm{M}]_{\text {Ref }} /[\mathrm{Fe}]_{\text {Ref }}}
$$

where EF represent the enrichment factor; $[M]_{\text {sample }}$ is the metal concentration $M$ in the sample; $[\mathrm{Fe}]_{\text {sample }}$ is the concentration of iron in the sample; $[\mathrm{M}]_{\mathrm{Ref}}$ is the concentration of metal $\mathrm{M}$ in the reference material and $[\mathrm{Fe}]_{\mathrm{Ref}}=$ concentration of iron in the reference material (Okuo \& Ndiokwere, 2006).

Pollution is the accumulation of a compound in such a quantity that it can induce a danger for living organisms or compromise the usual use of the receiving environment (Chassin et al., 1996). Thus, the geoaccumulation index (Igeo) is used to evaluate the pollution of soils or sediments by metals as indicated in the equation of Müller (1969):

$$
\text { Igeo }=\log 2\left(\frac{\mathrm{Cn}}{1.5 \mathrm{Bn}}\right)
$$

where Igeo represent geoaccumulation Index; $\log 2$ is logarithm of base 2; $\mathrm{Cn}$ is measured concentration in element $\mathrm{n}$; $\mathrm{Bn}$ is geochemical background concentration for element $\mathrm{n}$ and 1.5 is the geochemical background exaggeration factor, whose function is to take into account the natural fluctuations of the geochemical background.

Metal contamination at the soil surface is associated with a cocktail of contaminants rather than a single metal element (Lee et al., 2001). Thus, the soil pollution index (PI) identifies multiple element contamination that results in increased metal toxicity (El Hachimi et al., 2014). It is used to assess the overall 
toxicity of a contaminated soil that is calculated from the average of the metal concentrations ratio in soil samples to the limit guidelines. In this study, the pollution index is calculated by the following equation with the CCME (Canadian Council of Ministers of the Environment) limit values.

$$
\mathrm{IP}=\frac{(\mathrm{Pb} / 70+\mathrm{Cd} / 3+\mathrm{Cr} / 64+\mathrm{Zn} / 200)}{4}
$$

A pollution index greater than 1 (IP $>1$ ) corresponds to polymetallic soil pollution.

\subsection{Mapping of Soil Parameters (pH and Trace Metal Element Content)}

The maps were made using ArcGIS software with chemical analysis data and geographic data. The method used is kriging interpolation. This analysis method allows the prediction by interpolation from the measurement points. This corresponds to the consideration of measured values within a larger or smaller neighborhood radius (SIGLES, 2020). Spatial interpolation is a method of statistical estimation of spatialized data. Its principle is that from measured and georeferenced point observations, it provides the most likely value of the observed parameter at any point of the spatial domain studied (Hengl, 2007). The result is a cartographic production of estimates at each point of a regular grid covering the study area.

To predict the value of an unsampled point from multiple observation points, the simplified mathematical formula for spatial interpolation can be likened to a weighted arithmetic mean of the observed values (Li \& Heap, 2014).

$$
\hat{Z}\left(x_{0}\right)=\sum_{i=1}^{n} \lambda_{i} z\left(x_{i}\right)
$$

where $\hat{Z}$ is the estimated value of the random variable at the point of interest $x_{0} ; Z$ is the observed value at the sample point $x_{i} ; \lambda_{i}$ is the weighting factor assigned to that sample point; and $\mathrm{n}$ is the number of samples used for estimation.

Among geostatistical methods, kriging is considered the optimal interpolation method for environmental phenomena, since it takes into account the spatial dependence structure of the data in order to minimize the prediction error. It can be used for both interpolation and extrapolation. It is the most accurate estimation method (Gratton, 2002). Spatial interpolation by kriging was therefore used in our study to predict the acidity and the level of heavy metal contamination of soils in our study area.

\section{Results}

\subsection{Selected Soil Properties}

The physical properties of the soil are presented in Table 1 . The soil at the landfill is sandy in texture with a high organic matter content. From this presence of organic matter, the cation exchange capacity of the soil is high with a good microbial activity and a good balance between humification and mineralization, translated by the $\mathrm{C} / \mathrm{N}$ ratio. 
Table 1. Selected soil characteristics.

\begin{tabular}{|c|c|c|c|c|c|c|c|c|}
\hline \multirow[b]{2}{*}{ Sampling area } & \multicolumn{3}{|c|}{$\begin{array}{c}\text { Particles size } \\
(\%)\end{array}$} & \multicolumn{4}{|c|}{$\begin{array}{l}\text { Organic Mater } \\
\quad\left(\mathrm{mg} \cdot \mathrm{kg}^{-1}\right)\end{array}$} & \multirow[t]{2}{*}{$\begin{array}{c}\text { CEC } \\
\left(\mathrm{cmol}^{+} \mathrm{kg}^{-1}\right)\end{array}$} \\
\hline & Clay & Silt & Sand & $\mathrm{C}$ & $\mathrm{N}$ & $\mathrm{MO}$ & $\mathrm{C} / \mathrm{N}$ & \\
\hline Landfill & 21.30 & 1.55 & 77.15 & 22,600 & 2400 & 38,962 & 9.42 & 7.92 \\
\hline Surrounding soil & 8.55 & 10.55 & 80.90 & 10,500 & 2100 & 18,100 & 5.00 & 5.20 \\
\hline Control & 18.00 & 3.00 & 79.20 & 13,600 & 1300 & 23,400 & 10.6 & 8.72 \\
\hline
\end{tabular}

The $\mathrm{pH}_{\mathrm{KCl}}$ is on average $-0.25 \mathrm{pH}$ units lower compared to $\mathrm{pH}_{\text {water }}$ (Table 2). Comparison of the sampling areas at the site shows a difference between the $\mathrm{pH}$ of the landfill and the surrounding soils. Although this difference is not significant, regardless of $\mathrm{pH}\left(\mathrm{H}_{2} \mathrm{O}\right.$ or $\left.\mathrm{KCl}\right)$, the landfill soils have $\mathrm{pH}$ values that are on average $0.45 \mathrm{pH}$ units higher compared to the surrounding soil area. In detail, the $\mathrm{pH}_{\text {water }}$ of the landfill soils ranges from 6.84 to 7.77 with an average of 7.33 while in the surrounding soils, the $\mathrm{pH}_{\text {water }}$ ranges from 5.2 to 7.33 with an average of 6.98 . The $\mathrm{pH}_{\mathrm{KCl}}$ of the landfill soils ranges from 6.67 to 7.44 with an average of 7.08 while in the surrounding soils it ranges from 5.11 to 7.24 with an average of 6.76. Regardless of $\mathrm{pH}\left(\mathrm{H}_{2} \mathrm{O}\right.$ or $\left.\mathrm{KCl}\right)$, the results indicate significantly higher $\mathrm{pH}$ values in the landfill soils than in the surrounding soils. These average $\mathrm{pH}$ values $\left(\mathrm{H}_{2} \mathrm{O}\right.$ and $\left.\mathrm{KCl}\right)$ of the study site are significantly higher than those of the control soil $\left(\mathrm{pH}_{\text {water }}=5.8\right.$ and $\left.\mathrm{pH}_{\mathrm{KCl}}=4.5\right)$.

\subsection{Soil Metal Content and Contamination Level}

\subsubsection{Trace Metal Content of the Landfill Site Soils}

The results of the analyses of variance of the investigated trace metal element contents $(\mathrm{Pb}, \mathrm{Cd}, \mathrm{Cr}$, and $\mathrm{Zn})$ of soil samples and their general background statistics are reported in Table 2 . The heavy metal contents at the landfill site show that the landfill site soil is enriched in analyzed heavy metal compared to the control soil and relative contents of the upper continental crust (Table 2). The quartiles indicate a wide variation in levels for a given element. Indeed, the statistical data show that for the soil samples, $60 \%$ for $\mathrm{Pb}, 95 \%$ for $\mathrm{Zn}$ and $\mathrm{Cr}$ and $100 \%$ for Cd are higher than the UCC. In comparison with the control soil, the proportions of samples with levels above the control are $70 \%$ for $\mathrm{Pb}, 99 \%$ for $\mathrm{Cr}$ and $100 \%$ for $\mathrm{Zn}$ and $\mathrm{Cd}$. These data indicate an accumulation of heavy metal in the soil at the M'ploussoué landfill site. Cadmium (Cd) and $\mathrm{Zn}$ are the most abundant trace metals in the soil at the landfill site, followed by $\mathrm{Cr}$ and $\mathrm{Pb}$. Comparison of the sampling areas indicates that there is no difference in the overall means of $\mathrm{Pb}$ and $\mathrm{Cd}$ between the landfill samples and the surrounding soils. On the other hand, the $\mathrm{Cr}$ and $\mathrm{Zn}$ contents of the landfill soils are significantly and respectively $24 \%$ and $18 \%$ higher than the contents of the surrounding soil samples.

\subsubsection{Assessment of the State of Site Contamination}

Table 2 presents enrichment factor values in the landfill soils. $\mathrm{Cd}$ is the metal 
Table 2. Descriptive statistics of the studied parameters.

\begin{tabular}{|c|c|c|c|c|c|c|c|c|c|c|c|c|c|c|c|}
\hline \multirow[b]{2}{*}{ Parameters } & \multirow[b]{2}{*}{$\mathrm{n}$} & \multicolumn{4}{|c|}{ Landfill } & \multicolumn{10}{|c|}{ Surrounding soil } \\
\hline & & Min & $\operatorname{Max}$ & Median & Mean & SD & $\mathrm{CV} \%$ & Min & Max & Median & Mean & $\mathrm{SD}$ & $\mathrm{CV} \%$ & $\mathrm{UCC}^{\star}$ & $\mathrm{CCME}^{\star}$ \\
\hline $\mathrm{pH}\left(\mathrm{H}_{2} \mathrm{O}\right)$ & 71 & 6.84 & 7.77 & 7.32 & 7.33 & 0.19 & 2.60 & 5.20 & 7.33 & 7.08 & 6.98 & 0.36 & 5.22 & & \\
\hline $\mathrm{pH}(\mathrm{KCl})$ & 71 & 6.67 & 7.44 & 7.06 & 7.08 & 0.15 & 2.15 & 5.11 & 7.24 & 6.91 & 6.76 & 0.43 & 6.38 & & \\
\hline $\mathrm{Pb}\left(\mathrm{mg} \cdot \mathrm{kg}^{-1}\right)$ & 71 & 5.57 & 104.83 & 18.95 & 25.03 & 18.39 & 73.48 & 7.50 & 58.55 & 16.60 & 20.41 & 11.95 & 58.54 & 17 & 70 \\
\hline $\mathrm{Cd}\left(\mathrm{mg} \cdot \mathrm{kg}^{-1}\right)$ & 71 & 14.72 & 54.90 & 31.11 & 31.55 & 10.04 & 31.81 & 16.02 & 87.77 & 31.82 & 32.20 & 10.89 & 0.34 & 0.1 & 3 \\
\hline $\mathrm{Cr}\left(\mathrm{mg} \cdot \mathrm{kg}^{-1}\right)$ & 71 & 14.08 & 268.32 & 46.50 & 56.35 & 35.17 & 62.40 & 19.72 & 103.68 & 38.63 & 42.87 & 15.89 & 37.06 & 35 & 64 \\
\hline $\mathrm{Zn}\left(\mathrm{mg} \cdot \mathrm{kg}^{-1}\right)$ & 71 & 36.41 & 876.96 & 257.26 & 313.26 & 194.18 & 61.99 & 42.36 & 961.56 & 213.46 & 254.66 & 149.47 & 58.69 & 52 & 200 \\
\hline $\mathrm{EF}-\mathrm{Pb}$ & 71 & 0.72 & 18.58 & 2.22 & 3.14 & 2.91 & 0.93 & 1.01 & 12.08 & 2.54 & 3.28 & 2.12 & 0.65 & & \\
\hline $\mathrm{EF}-\mathrm{Cd}$ & 71 & 202.38 & 1710.16 & 619.70 & 728.13 & 410.88 & 0.56 & 378.06 & 3520.99 & 987.11 & 1004.89 & 477.14 & 0.47 & & \\
\hline $\mathrm{EF}-\mathrm{Cr}$ & 71 & 1.13 & 12.35 & 2.96 & 3.18 & 1.58 & 0.50 & 1.27 & 7.79 & 3.35 & 3.37 & 1.03 & 0.30 & & \\
\hline $\mathrm{EF}-\mathrm{Zn}$ & 71 & 1.94 & 35.89 & 11.74 & 12.60 & 8.05 & 0.64 & 2.73 & 55.39 & 12.01 & 13.57 & 7.93 & 0.58 & & \\
\hline Igeo- $\mathrm{Pb}$ & 71 & -2.07 & 2.16 & -0.28 & -0.19 & 0.09 & -46.48 & -1.65 & 1.32 & -0.52 & -0.41 & 0.08 & -18.30 & & \\
\hline Igeo-Cd & 71 & 3.70 & 5.60 & 4.76 & 4.72 & 0.05 & 0.97 & 3.83 & 6.28 & 4.83 & 4.78 & 0.04 & 0.87 & & \\
\hline Igeo-Cr & 71 & -0.90 & 3.35 & 0.82 & 0.91 & 0.07 & 7.90 & -0.41 & 1.98 & 0.55 & 0.62 & 0.05 & 7.71 & & \\
\hline Igeo-Zn & 71 & 1.46 & 6.05 & 4.28 & 4.25 & 0.10 & 2.42 & 1.68 & 6.18 & 4.03 & 4.09 & 0.07 & 1.74 & & \\
\hline PI & 71 & 0.35 & 5.95 & 1.70 & 2.08 & 1.35 & 64.62 & 0.40 & 8.05 & 2.71 & 2.51 & 1.41 & 60.34 & & \\
\hline
\end{tabular}

UCC: Upper Continental Crust; CCME: Canadian Cuncil of Ministers of the Environment; EF: Enrichment Factor; PI: Pollution index.

trace element that exhibits extremely high enrichment $(\mathrm{EF}>40)$ in the landfill soils with significantly high enrichment factor in the surrounding soils relative to the landfill soils. Zinc shows significant enrichment in the study site soils (EF between 5 and 20) with EF values that are not statistically different from the landfill to the surrounding soils. In contrast, $\mathrm{Cr}$ and $\mathrm{Pb}$ show moderate levels of enrichment with enrichment factors that are not statistically different from the landfill to surrounding soils.

The pollution index IP calculated for the study site is reported in Table 2. The results obtained show IP values that are greater than unity in both the landfill and surrounding soils. The calculation of Igeo shows that the soil at the study site has a variable level of pollution from one element to another. The basic statistical data of the geoaccumulation indices of the different metals are given in Table 2. According to the classification of Müller (1969), the results reveal that the soils of the landfill site are not polluted with lead (Igeo $<0$ ). On the other hand, the soils show extreme $\mathrm{Cd}$ and $\mathrm{Zn}$ contamination (with an Igeo between 4 and 5). These soils show moderate contamination for $\mathrm{Cr}$ with an Igeo between 0 and 1 which is significantly high in the landfill soils compared to the surrounding soils. Although the pollution indices are higher for $\mathrm{Pb}, \mathrm{Cd}$ and $\mathrm{Zn}$ in the landfill soils than the surrounding soils, these pollution indices are not statistically different from the surrounding soil dome (Figure 2). 


\subsection{Spatial Distribution of Chemical Parameters at the Landfill Site}

\subsubsection{Spatial Distribution of $\mathrm{pH}$}

Figure 3 shows the map of $\mathrm{pHwater}$ and $\mathrm{pH}_{\mathrm{KCl}}$ at the study site. The spatial distribution map shows four $\mathrm{pH}$ ranges characterized as "very acidic to acidic" (5.20 to 6.20 ), "slightly or weakly acidic" (6.20 to 6.70), "weakly acidic to neutral" (6.70 to 7.20), and "weakly alkaline" (7.20 to 7.70) (Figure 3(A)). Below these labels, $2.11 \%$ of the surface was very acidic to acidic. This surface is located in the southwestern region of the site in the bare soil sampling area. $5.63 \%$ of the surface is weakly acidic and located in the central area of the site. $46.48 \%$ of the

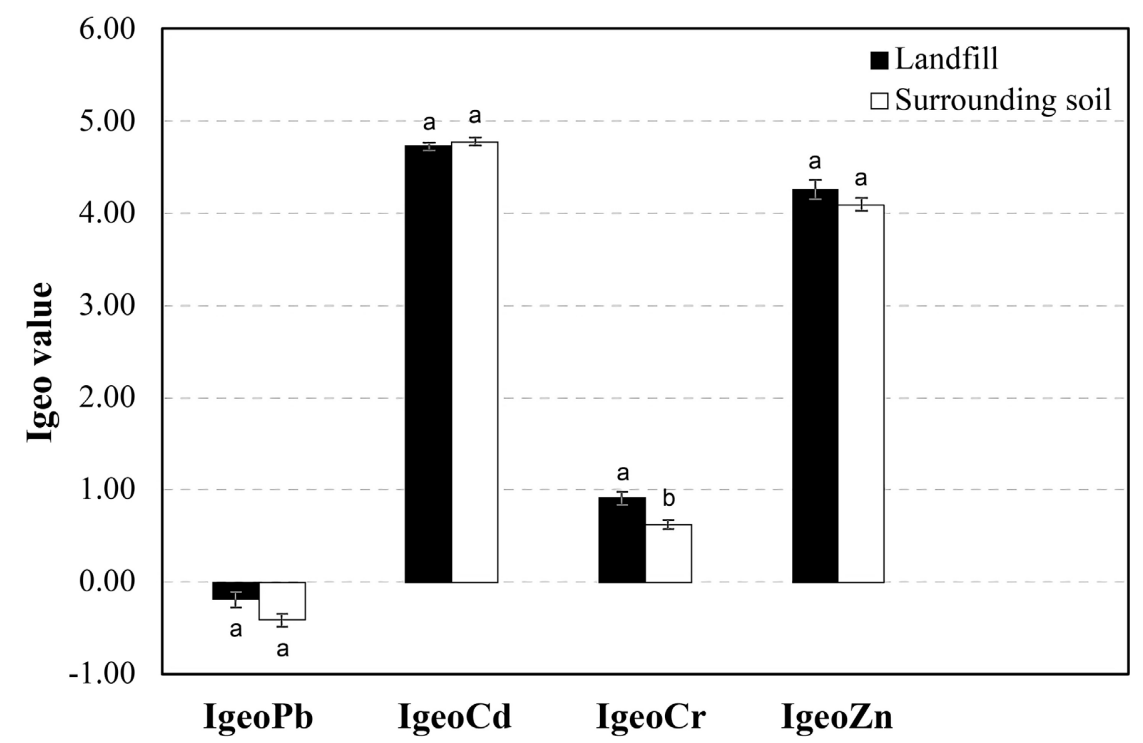

Figure 2. Geoaccumulation indices of $\mathrm{Pb}, \mathrm{Cd}, \mathrm{Cr}$ and $\mathrm{Zn}$ in landfill and surrounding soil.
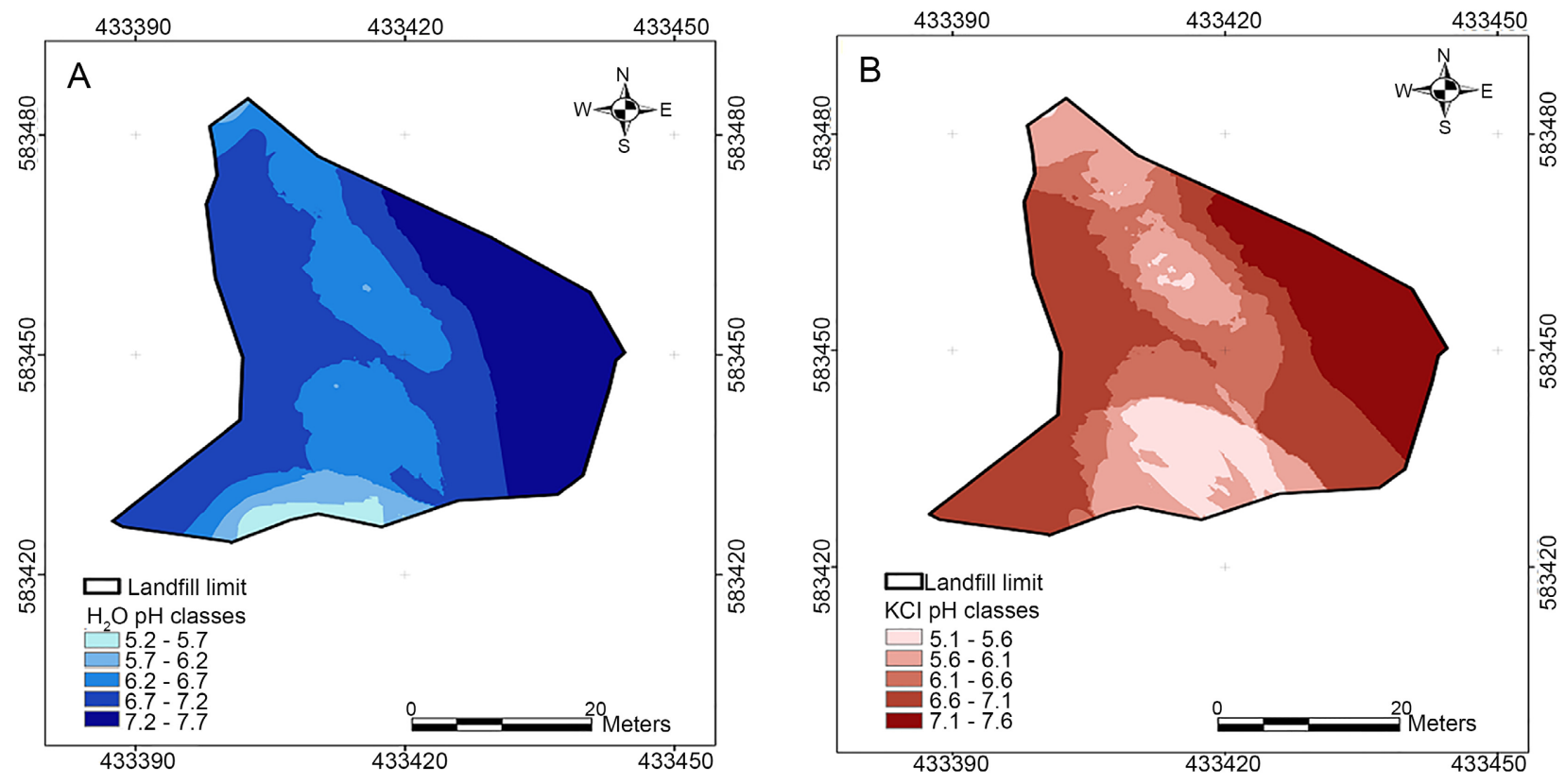

Figure 3. Spatial distribution map of soil $\mathrm{pH}$ at the study site. $\mathrm{pH}_{\text {water }}$ map (A) and $\mathrm{pH} \mathrm{KCl}_{\mathrm{map}}(\mathrm{B})$. 
surface is weakly acidic to neutral and corresponds to the western and eastern area of the site. Approximately $45.78 \%$ of the site is weakly alkaline and corresponds to the eastern edge of the landfill site. The spatial distribution of $\mathrm{pH}_{\mathrm{KCl}}$ which provides an indication of the potential acidity of the landfill soil indicates low $\mathrm{pH}$ in the Central, Northeast areas with a more pronounced acidity trend in the Southeast (Figure 3(B)).

\subsubsection{Spatial Distribution of Heavy Metal on the Site}

Maps of the spatial distribution of heavy metal concentrations are shown in

Figure 4. The spatial distribution of the analyzed heavy metal shows variations
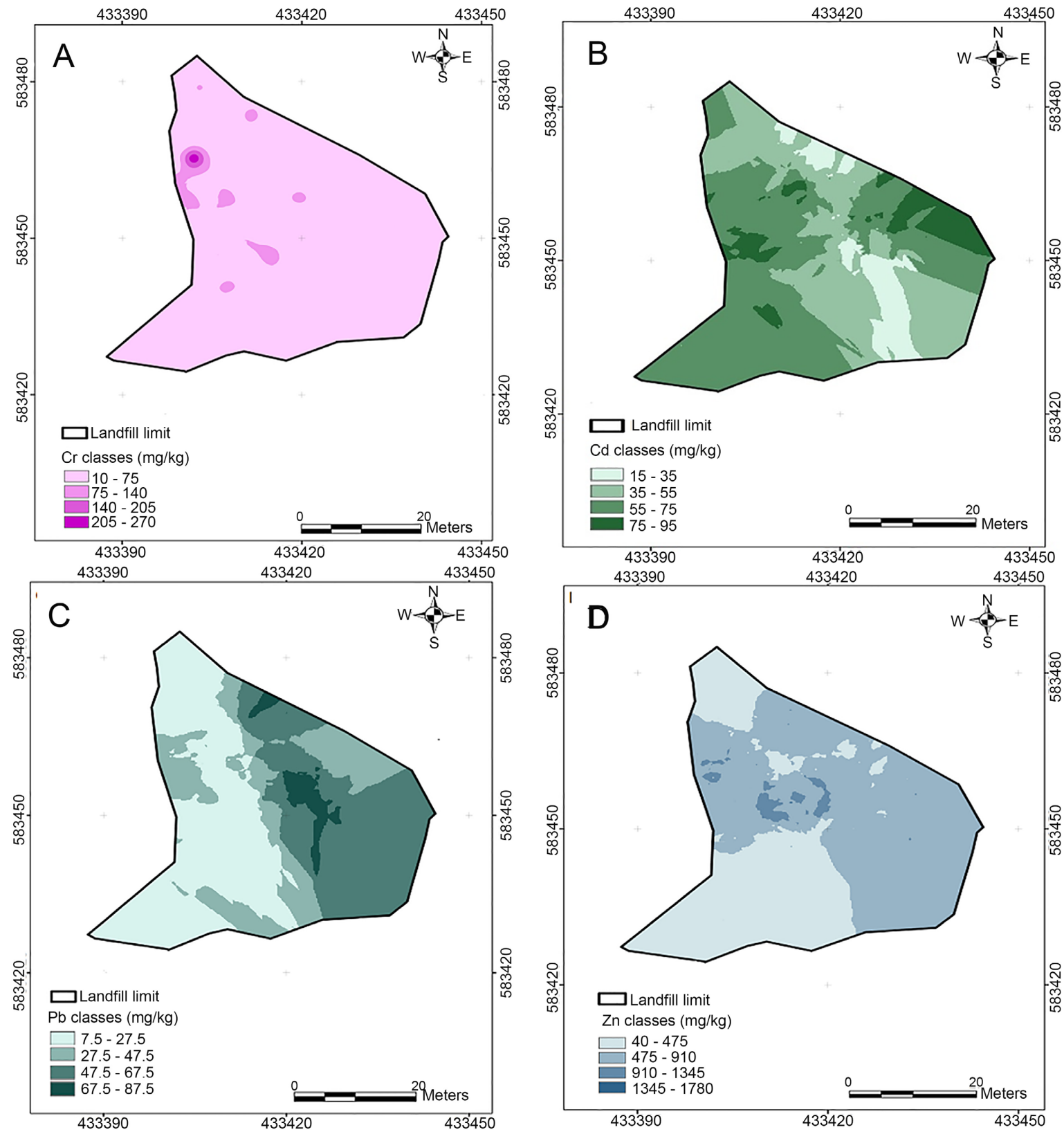

Figure 4. Spatial distribution map of trace metal content in the study site soils. Cr content map (A), Cd content map (B), $\mathrm{Pb}$ content map (C) and $\mathrm{Zn}$ content map (D). 
and fairly high concentration spots on the landfill site. The distribution of $\mathrm{Cr}$, although having concentration spots in the northeast of the site, remains generally homogeneous over the entire site (Figure $4(\mathrm{~A})$ ). These concentration spots in this part have heavy metal contents between 205 and $270 \mathrm{mg} \cdot \mathrm{kg}^{-1}$ and correspond to the landfill soils. For $\mathrm{Cd}$, the distribution of the content shows that this element is less concentrated in the central part of the landfill site than in the surrounding soil part (Figure 4(B)). In this central part, the contents vary between 16 and $35 \mathrm{mg} \cdot \mathrm{kg}^{-1}$, while the highest contents are between 75 and $95 \mathrm{mg} \cdot \mathrm{kg}^{-1}$. $\mathrm{The} \mathrm{Pb}$ map shows two clearly distinct areas (Figure $4(\mathrm{C})$ ). The highest $\mathrm{Pb}$ concentrations are found in the center, north, east and south of the site with peak areas (ranging from 67.5 to $87.5 \mathrm{mg} \cdot \mathrm{kg}^{-1}$ ) in the center and north corresponding to the landfill soils. Similar to $\mathrm{Pb}$, the analyzed soil samples show the highest $\mathrm{Zn}$ levels in the surrounding soils, except in the Southwest and Northwest (Figure 4(D)). The soil samples show a gradient of content from lowest to highest from northwest to southeast, from the landfill soils to the surrounding soils. A few small areas with peak contents between 1345 and $1780 \mathrm{mg} \cdot \mathrm{kg}^{-1}$ appear in the Central and Western parts that correspond to the landfill soils.

\subsubsection{Spatial Distribution of Geoaccumulation Indices at the Site}

The pollution distribution maps of the study site represented by the geoaccumulation indices are shown in Figure 5. The geoaccumulation indices are not homogeneously distributed over the entire landfill site. The results show that $\mathrm{Cr}$ pollution on the site varies from class 0 to class 4 with unpolluted areas in the northwest and east $($ Igeo $<0)$ to heavily polluted areas on the west side of the site. The entire southern and southwestern area representing bare soil is moderately polluted (Igeo between 0 and 2) (Figure 5(A)). With regard to $\mathrm{Cd}$, the results suggest that the site is entirely polluted with the northern zone showing the lowest pollution intensity (Igeo between 3.7 and 4.22) of the site. This area, corresponding to the landfill soils, indicates a highly polluted intensity according to the pollution classification. The extremely polluted areas (Igeo $>5$ ) are located on the eastern and western areas of the site with a marked effect on the southeastern area of surrounding soils (Figure 5(B)). The $\mathrm{Pb}$ Igeo distribution map shows overall an unpolluted (West zone) to moderately polluted (East zone) site, landfill and surrounding soils included (Figure 5(C)). The zinc map indicates a fully polluted site regardless of the sampling area. However, it should be noted that the North, East, West (landfill soils), and Southeast (surrounding soils) zones indicate extreme pollution (Igeo $>4$ ) (Figure $5(D))$.

\section{Discussion}

\subsection{Physico-Chemical Parameters of the Landfill Soil}

The results of this study show that there is variability between the physico-chemical parameters of the soil samples on the one hand and the distribution of these parameters on the site of the former landfill on the other. The landfill soils showed a high clay content while the bare soil showed a high sand content. 

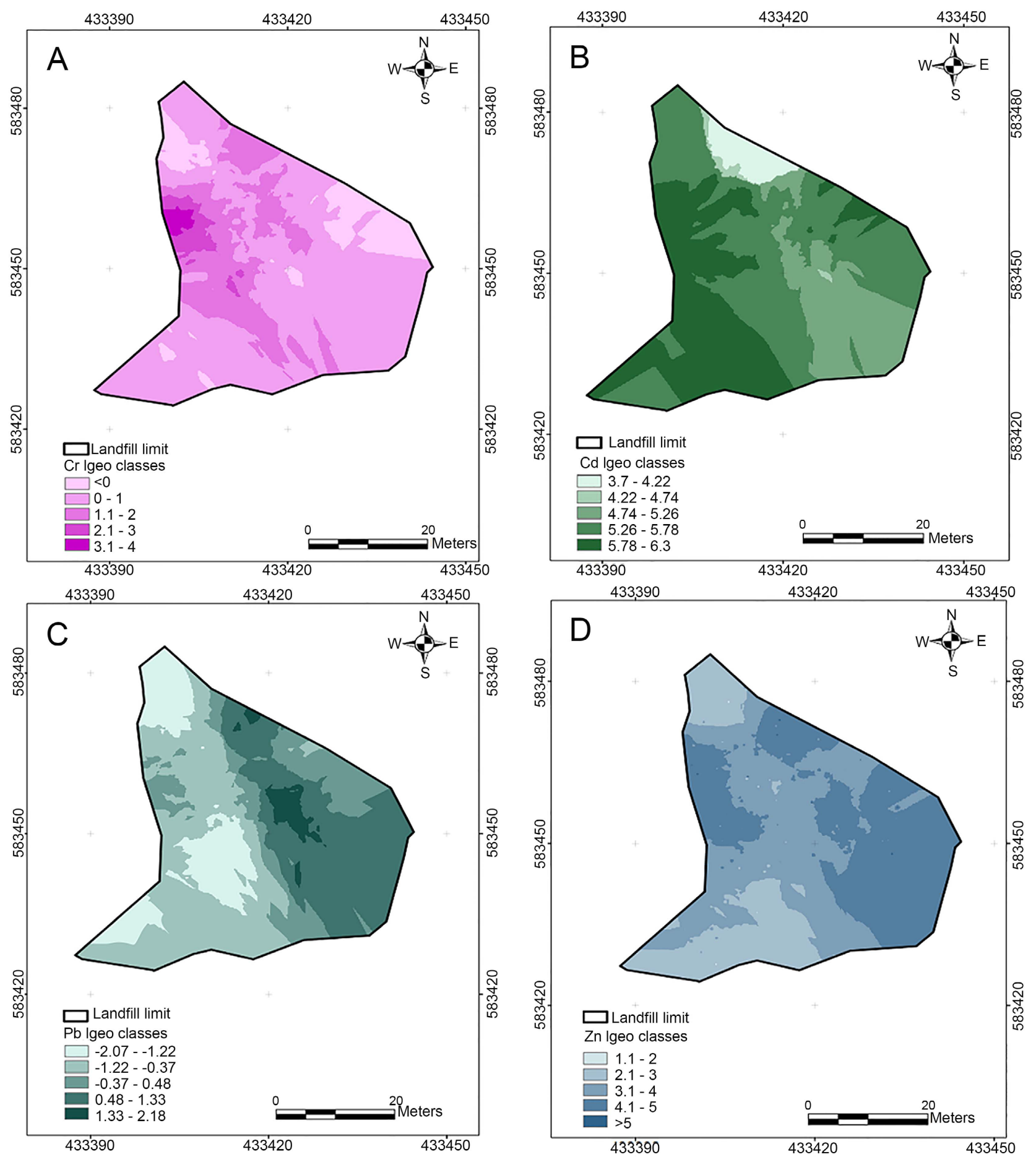

Figure 5. Spatial distribution map of soil geoaccumulation indices for the study site. Igeo Cr map (A), Igeo Cd map (B), Igeo $\mathrm{Pb}$ map (C), Igeo Zn map (D).

The results also showed a good $\mathrm{C} / \mathrm{N}$ ratio with high average organic matter content in the landfill soils of the site compared to the values of the soils surrounding the landfill and the control site soil. This ratio in the landfill soils could be related to the composition of the waste dumped at this site. Many studies have proven that organic matter in landfill soils comes from several types of waste 
categories, which are fermentable, degraded compounds, paper and cardboard (Koledzi et al., 2011, Akpaki et al., 2014, Chaer et al., 2016). In terms of pH, the soil samples show a slight variation depending on the sampling area. The results showed that the samples of the surrounding soils have a $\mathrm{pH}$ close to neutrality while those of the landfill soils evolve towards alkalinity. This trend of the $\mathrm{pH}$ of the studied soils from neutral to alkaline is attributed to the context of the landfill site. Indeed, the $\mathrm{pH}$ of the control soil is low compared to the $\mathrm{pH}$ of the study site soils. Several studies have shown that landfill soils have alkaline $\mathrm{pH}$ as reported for example on Akouédo landfill (Kouamé et al., 2006, Kouassi et al., 2014), Tangier landfill (Chaer et al., 2016), Agoè landfill in Togo (Bodjona et al., 2012), Islamabad landfill in Pakistan (Ali et al., 2014). This seems to confirm the anthropogenic origin of these neutral to alkaline $\mathrm{pH}$ values obtained at the study site. Thus these soil $\mathrm{pH}$ values would be due to the presence of certain categories of waste in the landfill, such as fermentable, paper and cardboard, wood ash (Koledzi et al., 2011) sources of the presence of certain alkaline and alkaline earth elements. These elements are present as exchangeable bases $\left(\mathrm{Ca}^{2+}, \mathrm{Mg}^{2+}\right.$, $\mathrm{Na}^{+}$and $\mathrm{K}^{+}$) and contribute to raising the soil $\mathrm{pH}$. However, resaerch on Oke-ogi landfill in Nigeria showed contrary results with acidic $\mathrm{pH}$ on the soil of the Oke-ogi landfill in Nigeria, which is believed to be the result of advanced degradation of organic matter at the site (Olufunmilayo et al., 2014).

\subsection{Control on Heavy Metal Sources and Distributions in Bonoua Landfill Soil}

Previous studies conducted throughout this area provided a preliminary characterization of the contamination. The conclusions of this work indicated that the soils of the former landfill have traces of heavy metal contamination that exceed thresholds on some occasions (Bongoua-Devisme et al., 2018). This is confirmed by the results of this study, which indicate high levels of certain metals (lead, cadmium, chromium, and zinc) at the Bonoua municipal dumpsite. At this dumping site, where all kinds of waste were dumped, analyses indicate average levels of $\mathrm{Pb}, \mathrm{Cd}, \mathrm{Cr}$ and $\mathrm{Zn}$ that exceed the Upper Continental Crust (UCC) levels (Wedepohl, 1995), and those of the control soil. These levels are also higher than the natural concentrations of maganesiferous soils in Côte d'Ivoire (14.32 $\mathrm{mg} \cdot \mathrm{kg}^{-1} ; 1.06 \mathrm{mg} \cdot \mathrm{kg}^{-1} ; 30.93 \mathrm{mg} \cdot \mathrm{kg}^{-1}$ and $110.73 \mathrm{mg} \cdot \mathrm{kg}^{-1}$ for $\mathrm{Pb}, \mathrm{Cd}, \mathrm{Cr}$ and $\mathrm{Zn}$ respectively (Nangah et al., 2013). These results thus seem to reveal an anthropogenic source of metals at the landfill site. Indeed, studies by several authors have revealed that the presence of metals in landfill soils would be related to the accumulation of various types of waste encountered on these sites (Soumaré et al., 2003; Biaou et al., 2019). A priori, this deduction on the anthropic origin of heavy metal seems to be confirmed by the presence on the site of paint waste, incinerated tire remnants, electronic products (car batteries, telephones, computers, used batteries), light bulbs and electric tubes, medical waste, a large amount of plastic waste (Kouamé et al., 2006; Ekengele et al., 2016). In addition, the findings of several studies have confirmed that landfills are the important 
sources of soil heavy metal contamination (Bartnikas, 2012; Olufunmilayo et al., 2014). However, some authors claim that the obtained high concentrations of heavy metal how that these concentrations in landfill soils do not depend on the age of the landfill, but on the source and composition of the waste (Sutherland, 2000; Olufunmilayo et al., 2014). Finally, the results of enrichment factor (EF) calculations all greater than 3 support that anthropogenic inputs are the source of $\mathrm{Pb}, \mathrm{Cd}, \mathrm{Cr}$, and $\mathrm{Zn}$ contamination in study site soils (Sutherland, 2000; Mil-Homens et al., 2006).

The comparison of heavy metal concentrations of Bonoua site to other landfills reveal that for lead, the content determined in this study remains significantly lower than that obtained in Côte d'Ivoire in the landfill soils of Yamoussoukro $\left(\mathrm{Pb}=163.7 \mathrm{mg} \cdot \mathrm{kg}^{-1}\right)$ (Yobouet et al., 2010), Songon $\left(\mathrm{Pb}=42.62 \mathrm{mg} \cdot \mathrm{kg}^{-1}\right)$ (Kambiré et Ouattara, 2018) and Akouedo (1500 mg. $\mathrm{kg}^{-1}$ ) (Kouamé et al., 2006) Elsewhere, this value is also lower than that results in the Ahfir-Saidia landfill in Morocco $\left(\mathrm{Pb}=359.13 \mathrm{mg} \cdot \mathrm{kg}^{-1}\right)$ (Nhari et al., 2014) but higher than the levels in Yenagoa landfill soils in Nigeria $\left(\mathrm{Pb}=15.45 \mathrm{mg} \cdot \mathrm{kg}^{-1}\right)$ (Amos-tautua et al., 2014). The cadmium content is higher than the levels obtained at the Yamoussoukro landfill $\left(\mathrm{Cd}=4.65 \mathrm{mg} \cdot \mathrm{kg}^{-1}\right)$, Akouédo landfill $\left(11 \mathrm{mg} \cdot \mathrm{kg}^{-1}\right)$ (Kouamé et al., 2006) in Côte d'Ivoire. This value is also high than the one obtained at Ayigya $(\mathrm{Cd}=$ $2.87 \mathrm{mg} \cdot \mathrm{kg}^{-1}$ ) (Odai et al., 2008) and at Boadi $\left(\mathrm{Cd}=0.28 \mathrm{mg} \cdot \mathrm{kg}^{-1}\right)$ in Kumassi, Ghana (Twumasi et al., 2016) and at Benin City $\left(\mathrm{Cd}=0.48 \mathrm{mg} \cdot \mathrm{kg}^{-1}\right)$ in Nigeria (Adaikpoh et al., 2012). For chromium, its content is lower than that of Akouédo $\left(\mathrm{Cr}=125 \mathrm{mg} \cdot \mathrm{kg}^{-1}\right)$ in Côte d'Ivoire (Kouamé et al., 2006) and Ahfir-Saidi $(\mathrm{Cr}=$ $63.62 \mathrm{mg} \cdot \mathrm{kg}^{-1}$ ) in Morocco (Nhari et al., 2014) and higher than the contents of landfill soils in Yenagoa $\left(\mathrm{Cr}=0.05 \mathrm{mg} \cdot \mathrm{kg}^{-1}\right.$ ) (Amos-tautua et al., 2014) and Benin City $\left(\mathrm{Cr}=0.21 \mathrm{mg} \cdot \mathrm{kg}^{-1}\right)$ in Nigeria (Adaikpoh et al., 2012). For zinc, its content at the site remains higher than that obtained at Ife $\left(\mathrm{Zn}=102.11 \mathrm{mg} \cdot \mathrm{kg}^{-1}\right)$ and Bode-Osi $\left(\mathrm{Zn}=63 \mathrm{mg} \cdot \mathrm{kg}^{-1}\right)$ in Nigeria (Amusan et al., 2005). This value is lower than the content obtained at the Tangier landfill $(\mathrm{Zn}=488-16,117$ $\mathrm{mg} \cdot \mathrm{kg}^{-1}$ ) in Morocco (Chaer et al., 2016).

The average levels show a variation from one sampling area to another. The soils in the landfill, i.e. where the waste mound is located, contain more lead, chromium and zinc. Cadmium levels are statistically identical, but the bare soil has higher levels than the dome. Thus the highest concentrations obtained are detected in the area of the landfill suggesting that the waste is the source of the contamination. The map that provides information on the spatial distribution of these heavy metal in the surface soil was structured in a heterogeneous way. Indeed, a preferential accumulation is observed in the area of the landfill, followed by a more or less pronounced decrease of the contents as one moves away from it. This spatial distribution of heavy metal could be linked to several factors, namely anthropogenic activities and soil properties. First, this distribution would be due to the heterogeneity, quantity and non-uniform degradation of these wastes deposited randomly on the site. Second, the positive correlations observed between $\mathrm{Pb}-\mathrm{Zn}$ and $\mathrm{Cr}-\mathrm{Zn}$ suggest possible common sources of conta- 
mination from anthropogenic activities or these elements are likely to be found together at the landfill site. Finally, other factors to be considered in the spatial distribution of $\mathrm{Pb}, \mathrm{Cd}, \mathrm{Cr}$ and $\mathrm{Zn}$ are physico-chemical parameters. It is known in the literature that $\mathrm{pH}$ is one of the important factors governing the retention of metal cations (Kabata-Pendias \& Pendias, 2001). However, correlations determined for all soils showed that there was no correlation between heavy metal concentrations and $\mathrm{pH}$. With $\mathrm{pH}$ near neutral or alkaline, metals would precipitate. However, the positive correlation between $\mathrm{Zn}$ and $\mathrm{pH}_{\mathrm{KCl}}$ seems to inform about the mobility and availability of metals with a tendency to acidification. The high levels of heavy metal in the landfill would then be related to the organic matter content. Several authors have shown that organic matter plays a very important role in the retention of metals (Dumat et al., 2001, Hargreaves et al., 2008). This is one of the reasons that could reflect their low mobility on the site (Baize, 1997), and induce their high content in the landfill soils. It should also be noted that the high clay content might also favor the retention of these heavy metals. Indeed, the clay fraction has negative charges and favors their fixation (Bur, 2008). At the level of the surrounding soils, the homogeneous distribution of heavy metal could be explained by the high rate of sand in this area.

\subsection{Pollution Assessment of the Landfill Site}

The assessment of environmental quality, based on heavy metal content in soil, involves the use of different pollution indices: the enrichment factor (EF), the geoaccumulation index (Igeo) and the pollution index (PI). First, the enrichment factor was used to determine the metal inputs to the landfill soil by assessing the pollution intensity by separating the anthropogenic signal from the natural signal. The results showed an extremely high enrichment for cadmium indicating extreme contamination followed by zinc which has a significant enrichment at the site. As for lead and chromium, the results showed moderate contamination. Secondly, the geoaccumulation indices for metals confirm the results obtained with the enrichment factor calculations (Hayzoun, 2004). The soils at the site, regardless of the sampling area, show Igeo values between 4 and 5 indicating a site that is highly to extremely polluted with cadmium and zinc. Chromium Igeo values less than 1 indicate moderate site pollution of this element. On the other hand, lead Igeo values below 0 suggest that the site is not polluted with this element. The Igeo values of the study site compared to those of other landfills reveal varying levels of pollution. The calculated Igeo show moderate contamination in $\mathrm{Cr}, \mathrm{Pb}, \mathrm{Zn}$ and $\mathrm{Cd}$ in the Sidi Belattar landfill soil and highly contaminated in $\mathrm{Cd}$ and $\mathrm{Pb}$ in the Yellel landfill soil in Algeria (Ouiza, 2018). Studies in Ouagadougou, Burkina Faso, showed that the Karpala and Dagnoin landfill soils were moderately contaminated with $\mathrm{Zn}$ and $\mathrm{Pb}$ (Bambara et al., 2021). The results of the Igeo confirm those of the FE in the present study, except for the $\mathrm{Pb}$ contamination for which the Igeo do not confirm the results obtained with the FE. Heavy metal pollution is closely related to anthropogenic activities in this 
area (Ekengele et al., 2016). Thus, the maps of the spatial distributions of the determined Igeo's capture the pollution of these elements at the site. A general view of the maps shows a dominant pollution distribution pattern on the dome for lead, chromium, and zinc in contrast to cadmium, which has a rather dominant metal pollution on the bare soil. Finally, the PI results obtained reveal average values that are greater than unity regardless of the sampling area. These pollution index values thus confirm a polymetallic pollution of the soils of the study site.

\subsection{Recommendations for Soil Remediation}

The EFs, Igeo, PIs and distribution maps of $\mathrm{Pb}, \mathrm{Cd}, \mathrm{Cr}$ and $\mathrm{Zn}$ pollution recorded in the framework of this study for the landfill soils underline the extremely harmful character of these abandoned landfill soils without rehabilitation. This site could constitute a perennial source of contamination for the environment because the results of the study converge towards a report of more or less high pollution in $\mathrm{Cd}, \mathrm{Zn}, \mathrm{Cr}$ and $\mathrm{Pb}$. The soils of the landfill site could then become a potential source of direct or indirect diffusion of these heavy metal into the environment via water, dust, plants or animals. The populations are thus exposed to major risks because they consume the products from this site. The topography of the study area shows that the site is located at the top of a toposequence at an altitude of $54 \mathrm{~m}$. Rainwater can wash away the polluted soil and migrate to the lower elevations where there are several streams. In this regard, recent research on the same site showed a significant presence of heavy metal in the lowland gleysols not far from the study site with concentrations of 116, 177, 247.7 and $318.1 \mathrm{mg} \cdot \mathrm{kg}^{-1}$ respectively for cadmium, chromium, lead and zinc (Guéablé, 2016). According to this author, these high levels appear to be related to leaching and accumulation of heavy metal from the landfill. It should be noted that the site of the landfill, which is very rich in organic matter, serves as a good place for the residents to grow vegetables, banana trees, and other edible plants. It is known in the literature that heavy metal can be bioaccumulated in plant tissues (Cheng, 2003; Akan et al., 2013). These studies indicate clear evidence that high levels of heavy metal can be harmful to plants and indirectly contaminate animals and humans that consume these agricultural products. Studies have reported that continued consumption of heavy metal from vegetables and other foodstuffs can lead to altered health status in animals and humans (Turkdogan et al., 2013).

At the end of the analysis, the pollution of the site with lead, cadmium, chromium and zinc can affect the quality of soils and agricultural products, surface water and groundwater, which can have a negative impact on the health of exposed populations. For all these reasons, it is of utmost urgency to proceed with the rehabilitation of this polluted site to reduce the environmental and health risks. To provide appropriate solutions for effective remediation of the landfill site, methods of scavenging by plants such as Acacia are ecological avenues little 
explored. This approach has several advantages over conventional methods used in contaminated land management (physico-chemical methods) (Kumar et al., 1995; Chaney et al., 1997). Unlike the latter, it rarely involves excavation and soil transport. This contributes greatly to its low environmental impact and affordability. In addition to these economic and environmental advantages, the aesthetic and ecological characteristics of the plant systems used in phytoremediation (Desjardins, 2018), its durability and its applicability over large areas. By definition, phytoremediation (or phytoremediation) is a set of techniques based on the use of plants with the objective, the depollution of soils, sediments or waters, in association with or without microorganisms (Salt et al., 1998, Ali et al., 2013). Phytoremediation covers the different methods of phytostimulation, phytodegradation, phytovolatilization, phytostabilization and phytoextraction (McGrath, 1998). The type of soil contamination determines the phytoremediation approach to be adopted. However, the heavy metal present $(\mathrm{Pb}, \mathrm{Cd}, \mathrm{Cr}$, and $\mathrm{Zn}$ ) in the site soil are varied in nature and have a heterogeneous distribution. Phytoremediation takes this complex situation into account, as the scientific literature mentions numerous plant species with natural soil remediation abilities. The main abilities are the ability to absorb and metabolize contaminants, or the ability to degrade organic compounds directly in the soil, through the production of root exudates and in association with the rhizosphere microbial community (Desjardins, 2018). Plant species with some of these capabilities and qualities are numerous, but few possess remediation abilities for multiple heavy metals at the same time. In a context of multiple contamination, such as the case of the study site, it then appears judicious to test different species in the laboratory in order to obtain a plant with the remediation ability that will be adapted to the site.

\section{Conclusion}

In the context of a rehabilitation of an urban park that had been used as a municipal landfill, this study was undertaken to understand the distribution of trace metals in the soils of the landfill and the surrounding soils. The results show that the soils have high levels of trace metals, including $\mathrm{Pb}, \mathrm{Cd}, \mathrm{Cr}$ and $\mathrm{Zn}$. The parameters Igeo, FE and IP also allowed to detect a polymetallic pollution of the former Bonoua landfill site with a more or less heterogeneous distribution of the pollution on the whole site. The high values of the enrichment factors obtained suggest an anthropic origin of these metallic trace elements in the soils of the site with an abundance following the order $\mathrm{Cd}>\mathrm{Zn}>\mathrm{Cr}>\mathrm{Pb}$ with however a strong heterogeneity in the soils of the site. This distribution would be linked on the one hand to the heterogeneous nature of the waste and on the other hand to the physico-chemical parameters of the soils, factors of the mobility and availability of the heavy metal in the soils. However, these soils present some good characteristics for vegetable growth. Therefore, in order to restore the chemical quality of these soils, soil remediation using plant is needed and consequently, the ability of tropical shrub (Acacia sp.) to extract metals from soils and stabilize them 
needs to be investigated in this type of soil in order to produce healthy vegetables in the urban area. In addition, the dynamics of heavy metals and their speciation in soils under the urban forest to be set up will be studied according to the seasons.

\section{Conflicts of Interest}

The authors declare no conflicts of interest regarding the publication of this paper.

\section{References}

Adaikpoh, E. O., \& Kaizer, N. A. (2012). Trace Metal Enrichment in Sediments from Otofure and Teboga Waste Dump Sites in Benin City, Nigeria. International Journal of Chemistry, 4, 14-27. https://doi.org/10.5539/ijc.v4n4p14

Akan, J. C. B., Kolo, G., Yikala, B. S., \& Ogugbuaja, V. O. (2013). Determinations of Some Heavy Metal in Vegetable Samples from Biu Local Government Area, Borno State, North Eastern Nigeria. International Journal of Environmental Monitoring and Analysis, 1, 40-46. https://doi.org/10.11648/j.ijema.20130102.11

Aké, G. E. (2010). Impacts de la variabilité climatique et des pressions anthropiques sur les ressources hydriques de la région de Bonoua (Sud-Est de la Côte d'Ivoire). Thèse de Doctorat, Université de Cocody, Abidjan.

Akpaki, O., Koledzi, E. K., Kwamivi, N. S., Baba, G., Koffi, K., \& Tchangbedji, G. (2014). Recherche de polluants inorganiques sur un ancien site de décharge d'ordures ménagères érigé en aire de jeux: Cas de Bè-Aveto à Lomé au Togo. International Journal of Biological and Chemical Sciences, 8, 766-776.

https://doi.org/10.4314/ijbcs.v8i2.33

Ali, H., Khan, E., \& Sajad, M. A. (2013). Phytoremediation of Heavy Metals. Concepts and Applications. Chemosphere, 91, 869-881. https://doi.org/10.1016/j.chemosphere.2013.01.075

Ali, S. M., Pervaiz A., Afzal, B., Hamid, N., \& Yasmin A. (2014). Open Dumping of Municipal Solid Waste and Its Hazardous Impacts on Soil and Vegetation Diversity at Waste Dumping Sites of Islamabad City. Journal of King Saud University-Science, 26, 59-65. https://doi.org/10.1016/j.jksus.2013.08.003

Amos-tautua, B. M. W., Onigbinde, A. O., \& Ere, D. (2014). Assessment of Some Heavy Metal and Physicochemical Properties in Surface Soils of Municipal Open Waste Dumpsite in Yenagoa, Nigeria. African Journal of environmental Science and Technology, 8, 41-47. https://doi.org/10.5897/AJEST2013.1621

Amusan, A. A., Ige, D. V., \& Olawale, R. (2005). Characteristics of Soils and Crops' Uptake of Metals in Municipal Waste Dump Sites in Nigeria. Journal of Human Ecology, 17, 167-171. https://doi.org/10.1080/09709274.2005.11905775

Baize, D. (1997). Teneurs en éléments traces métalliques dans les sols (France) (401 p). INRA (Institut national de la recherche agronomique).

Bambara, T. L., Doumounia, A., Ouédraogo, S., Kohio, N., \& Zougmoré, F. (2021). Assessment of the Physico-Chemical Parameters and Soil Pollution in Some Landfills at Ouagadougou. International Journal of Environmental Monitoring and Analysis, 9, 54-59. https://doi.org/10.11648/j.ijema.20210902.14

Bartnikas, T. B. (2012). Known and Potential Roles of Transferring in Iron Biology. BioMetals, 25, 677-686. https://doi.org/10.1007/s10534-012-9520-3 
Biaou, C. I., Hedible, S. C., Landeou, R. C., \& Boko, M. (2019). Impact des Décharges Sauvages des Déchets Solides sur les Sols à Cotonou. European Scientific Journal, 15, 94-104. https://doi.org/10.19044/esj.2019.v15n30p94

Bodjona, M. B., Kili, K. A., Tchegueni, S., Kennou, B., Tchangbedji, G., \& El Meray, M. (2012). Evaluation de la quantité des métaux lourds dans la décharge d'Agoè (Lomé-Togo): Cas du plomb, cadmium, cuivre, nickel et zinc. International Journal of Biological and Chemical Sciences, 6, 1368-1380. https://doi.org/10.4314/ijbcs.v6i3.38

Bongoua-Devisme, A., Bolou Bi, E., Kassin, K., Balland-Bolou-Bi, C., Gueable, Y., Adiaffi, B., Yao-Kouamé A., \& Djagoua, V. E. (2018). Assessment of Heavy Metal Contamination Degree of Municipal Open-Air Dumpsite on Surrounding Soils: Case of Dumpsite of Bonoua, Ivory Coast. International Journal of Engineering Research and General Science, 6, 27-42.

Bur, T. (2008). Impact anthropique sur les éléments traces métalliques dans les sols agricoles de Médi-Pyrenées. Implication en termes de limites et de charges critiques (374 p). Thèse de Doctorat, Université de Toulouse.

Chaer, I., El Cadi, A., Fakih, A. L., Khaddor, M., \& Brigui, J. (2016). Détermination du degré de contamination du site de la décharge, non contrôlée, de la ville de Tanger par quelques métaux lourds. Journal of Materials and Environmental Science, 7, 541-546.

Chaney, R. L., Malik, M., Li, Y. M., Brown, S. L., Brewer, E. P., Angle, J. S., \& Baker A. J. M. (1997). Phytoremediation of Soil Metals. Current Opinion in Biotechnology, 8, 279-284. https://doi.org/10.1016/S0958-1669(97)80004-3

Chapelle, G. (2013). L'incidence des pollutions urbaines sur les productions alimentaires en ville (35 p). Rapport Institut Bruxellois de Gestion de l'Environnement, Greenloop.

Chassin, P., Baize, D., Cambier, P., \& Sterkman, T. (1996). Les éléments traces métalliques et la qualité des sols. Impact à moyen et à long terme. Étude et gestion des sols, 3, 298-306.

Cheng, S. (2003). Heavy Metal Pollution in China: Origin, Pattern and Control. Environmental Science and Pollution Research, 10, 192-198. https://doi.org/10.1065/espr2002.11.141.1

Desjardins, D. (2018). Diversité végétale en phytoremédiation: La complémentarité fonctionnelle pour gérer efficacement la contamination multiple des sols (128 p). Thèse de doctorat de l'université de Montréal.

Dumat, C., Chiquet, A., Goody, D., Aubry, E., Morin, G., Juillot, F. et al. (2001). Metal Ion Geochemistry in Smelter Impacted Soils and Soil Solutions. Bulletin de la Société Géologique de France, 172, 539-548. https://doi.org/10.2113/172.5.539

Ekengele, N. L., Mabrey, S. S., \& Zo'o, Z. P. (2016). Évaluation de la contamination métallique des sols exposés à l'incinération des pneus d'automobiles dans la ville de Ngaoundéré (Cameroun). Journal of Materials and Environmental Science, 7, 4633-4645.

El Hachimi, M. L., Fekhaoui, M., Abidi, A. E., \& Rhoujatti, A. (2014). Contamination des sols par les métaux lourds à partir de mines abandonnées: Le cas des mines Aouli-Mibladen-Zeïda au Maroc. Cahiers Agricultures, 23, 213-219.

https://doi.org/10.1684/agr.2014.0702

Fang, T. H., Hwang, J. S., Hsiao, S. H., \& Chen, H. Y. (2006). Trace Metals in Seawater and Copepods in the Ocean Outfall Area Off the Northern Taiwan Coast. Marine Environmental Ressources, 61, 224-243. https://doi.org/10.1016/j.marenvres.2005.10.002

Fergusson, J. E. (Ed.) (1990). The Heavy Elements: Chemistry, Environmental Impact and Health Effects. Pergamon Press.

Gerth, A., Hebner, A., Kopielski, K., Schneider, P., \& Le Hung, A. (2016). Reuse of a 
closed landfill site. In Proceedings of the International Conference on Advanced Technology and Sustainable Development 2016 (ICATSD2016) (pp. 1388-1400).

Gratton, Y. (2002). Le krigeage: La méthode optimale d'interpolation spatiale. Institut National de la Recherche Scientifique (INRS), Eau-Terre-Environnement.

Guéablé, D. (2016). Étude des paramètres physico-chimiques de la décharge du parc M’Ploussoué de Bonoua au sud-est de la Côte d'Ivoire (75 p). Mémoire de Master de l'Université Félix Houphouet Boigny d'Abidjan.

Guety, T. P., Bolou Bi, E. B., Bongoua-Devisme, A. J., \& Koné, B. (2017). Metallic Trace Elements (MTE) in Soils and Plant Organs of Some Crop in Periurban of Abidjan (Ivory Coast). Advances in Agricultural Science, 5, 13-31.

Hargreaves, J. C., Adl, M. S., \& Warman, P. R. (2008). A Review of the Use of Composted Municipal Solid Waste in Agriculture. Agriculture, Ecosystems and Environment, 123, 1-14. https://doi.org/10.1016/j.agee.2007.07.004

Hayzoun, H. (2014). Caractérisation et quantification de la charge polluante anthropique et industrielle dans le bassin du Sebou (175 p). Thèse de doctorat de l'Université de Toulon et de Fès.

Hengl, T. (2007). A Practical Guide to Geostatistical Mapping of Environmental Variables (143 p). Office for Offcial Publicationof the European Communities.

Kabata-Pendias, A., \& Pendias, H. (2001). Trace Elements in Soil and Plants (3nd ed., p. 413). Chemical Rubber Company Press. https://doi.org/10.1201/9781420039900

Kambiré, B., \& Ouattara, S. K. (2018). Pollution du sol par les déchets ménagers solides dans la commune de Songon: Cas de Songon-agban. Revue Espace, Territoires, Sociétés et Santé, 1, 95-107.

Kanmani, S., \& Gandhimathi, R. (2013). Assessment of Heavy Metal Contamination in Soil Due to Leachate Migration from an Open Dumping Site. Applied Water Science, 3, 193-205. https://doi.org/10.1007/s13201-012-0072-Z

Kihampa, C., Mwegoha, W., \& Shemdoe, R. (2011). Heavy Metals Concentrations in Vegetables Grown in the Vicinity of the Closed Dumpsite. International Journal of Environmental Sciences, 2, 889-895.

Kim, Y. D., \& Lee, D.-G. (2009). Comparative Study on Leachate in Closed Landfill Sites: Focusing on Seasonal Variations. Journal of Material Cycles and Waste Management, 11, 174-182. https://doi.org/10.1007/s10163-008-0246-9

Kjeldsen, P., Barlaz, M. A., Rooker, A. P., Baun, A., Ledin, A., \& Christensen, T. H. (2002). Present and Long-Term Composition of MSW Landfill Leachate: A Review. Critical Reviews in Environmental Science and Technology, 32, 297-336. https://doi.org/10.1080/10643380290813462

Koledzi, K. E., Baba, G., Feuillade, G., \& Matejka, G. (2011). Caractérisation physique des déchets solides urbains à Lomé au Togo, dans la perspective du compostage décentralisé dans les quartiers. Revue Déchets Sciences et Techniques, 59, 14-22.

Kouamé, I. K., Gone, D. L., Savane, I., Kouassi, E. A., Koffi, K., \& Goula, B. T. A. (2006). Mobilité relative des métaux lourds issus de la décharge d'Akouédo et risque de contamination de la nappe du Continental Terminal (Abidjan-Côte d'Ivoire). Afrique Science, 2, 39-56.

Kouassi, E., Ahoussi, K., Koffi, Y., Kouame, K., Soro, N., \& Biemi, J. (2014). Caractérisation physico-chimique du lixiviat d'une décharge de l'Afrique de l'ouest: Cas de la décharge d'Akouedo (Abidjan-Côte d'Ivoire). Larhyss Journal, No. 19, 63-74. https://doi.org/10.4314/afsci.v2i1.61133 
Kumar, P., Dushenkov, V., \& Raskin, I. (1995). Phytoremediation: The Use of Plant to Remove Heavy Metal from Soil. Environmental Science and Technology, 29, 1232-1238. https://doi.org/10.1021/es00005a014

Lee, C. G., Chon, H. T., \& Jung, M. C. (2001). Heavy Metal Contamination in the Vicinity of the Daduk Au-Ag-Pb-Zn Mine in Korea. Applied Geochemistry, 16, 1377-1386. https://doi.org/10.1016/S0883-2927(01)00038-5

Li, J., \& Heap, A. D. (2014). Spatial Interpolation Methods Applied in the Environmental Sciences: A Review. Environmental Modelling and Software, 53, 173-189. https://doi.org/10.1016/j.envsoft.2013.12.008

Liu, W., Zhao, J., Ouyang, Z., Soderlund, L. \& Liu, G. (2005). Impacts of Sewage Irrigation on Heavy Metal Distribution and Contamination in Beijing, China. Environment International, 31, 805-812. https://doi.org/10.1016/j.envint.2005.05.042

McGrath, S. P. (1998). Phytoextraction for Soil Remediation. In R. R. Brooks (Ed.) Plants that Hyperaccumulate Heavy Metals (pp. 261-287). CAB International.

Mil-Homens, M., Stevens, R. L., Abrantes, F., \& Cato, I. (2006). Heavy Metal Assessment for Surface Sediments from Three Areas of the Portuguese Continental Shelf. Continental Shelf Research, 26, 1184-1205. https://doi.org/10.1016/j.csr.2006.04.002

Müller, G. (1969). Index of Geoaccumulation in Sediments of the Rhine River. Geojournal, 2, 109-118.

N'guettia, K. I. (2010). Gestion des ordures ménagères d'Abidjan: Diagnostic (52 p). Master de l'Institut International d'Ingénierie de l'Eau et de l'Environnement.

Nangah, K. Y., Angui, K. T. P., Kouakou, Y. K. N., Rusu, E., Yao-Kouamé, A., \& Savane, I. (2013). Teneurs en éléments traces métalliques (ETM) dans quelques sols manganésifères dérivés de matériaux volcano-sédimentaires de Côte d'Ivoire. International Journal of Innovation and Applied Studies, 2, 372-383.

Ngole, V. M., \& Ekosse, G. I. E. (2012). Copper, Nickel and Zinc Contamination in Soils within the Precincts of Mining and Landfilling Environments. International Journal of Environmental Science and Technology, 9, 485-494.

https://doi.org/10.1007/s13762-012-0055-5

Nhari, F., Sbaa, M., Vasel, J. L., Fekhaoui, M., \& El Morhit, M. (2014). Contamination des sols d'une décharge non contrôlée par les métaux lourds: Cas de la décharge Ahfir-Saidia (Maroc oriental). Journal of Materiels and Environmental Science, 5, 1477-1484.

Odai, S. N., Mensah, E., Sipitey, D., Ryo, S., \& Awuah, E. (2008). Heavy Metal Uptake by Vegetables Cultivated on Urban Waste Dumpsites: Case Study of Kumasi, Ghana. Research Journal of Environmental Toxicology, 2, 92-99. https://doi.org/10.3923/rjet.2008.92.99

Okuo, J. M., \& Ndiokwere, C. L. (2006). Elemental Concentration of Total Suspended Particulate Matter on Relation to Air Pollution in Niger Delta: A Case Study of Warri. Trends in Applied Science Research, 1, 91-96. https://doi.org/10.3923/tasr.2006.91.96

Olufunmilayo, O. O., Oludare, A. H., \& Oluwatoyin, D. (2014). Determination of Concentrations of Heavy metal in Municipal Dumpsite Soil and Plants at Oke-ogi, Iree, Nigeria. International Research Journal of Pure and Applied Chemistry, 4, 656-669.

Ouiza, O. A. (2018). Impact des décharges à ciel ouvert sur la qualité environnementale de l'Oued Cheliff (Algérie) (188 p). Thèse de doctorat Université de Perpignan Via Domitia / Université Abdelhamid Ibn Badis (Mostaganem, Algérie).

Rubio, B., Nombela, M. A., \& Vilas, F. M. (2000). Geochemistry of Major and Trace Elements in Sediments of the Ria de Vigo (NW Spain): An Assessment of Metal Pollution. 
Marine Pollution Bulletin, 40, 968-969. https://doi.org/10.1016/S0025-326X(00)00039-4

Salt, D. E., Smith, R. D., \& Raskin, I. (1998). Phytoremediation. Annual Review of Plant Physiology and Plant Molecular Biology, 49, 643-668. https://doi.org/10.1146/annurev.arplant.49.1.643

SIGLES (Systèmes d'Information Géographique et Liens Environnement-Santé). http://www.sigles-sante-environnement.fr/

Soro, N., Ouattara, L., Dongo, K., Kouadio, K. E., Ahoussi, K. E., \& Soro, G. (2010). Déchets municipaux dans le District d'Abidjan en Côte d'Ivoire: Sources potentielles de pollution des eaux souterraines. International Journal of Biological and Chemical Sciences, 4, 2203-2219. https://doi.org/10.4314/ijbcs.v4i6.64952

Soumaré, M., Tack, F. M. G., \& Verloo, M. G. (2003). Effects of a Municipal Solid Waste Compost and Mineral Fertilization on Plant Growth in Two Tropical Agricultural Soils of Mali. Bioresource Technology, 86, 15-20. https://doi.org/10.1016/S0960-8524(02)00133-5

Sutherland, R. A. (2000). Bed Sediment-Associated Trace Metals in an Urban Stream, Oahu, Hawaii. Environmental Geology, 39, 611-627.

https://doi.org/10.1007/s002540050473

Turkdogan, M. K., Kilicel, F., Kara, K., Tuncer, I., \& Uygan, I. (2003). Heavy Metal in Soil, Vegetables and Fruits in the Endemic Upper Gastrointestinal Cancer Region of Turkey. Environmental Toxicology and Pharmacology, 13, 175-179. https://doi.org/10.1016/S1382-6689(02)00156-4

Twumasi, P., Tandoh, M. A., Borbi, M. A., Ajoke, A. R., Owusu-Tenkorang, E., \& Okoro, R. (2016). Assessment of the Levels of Cadmium and Lead in Soil and Vegetable Samples from Selected Dumpsites in the Kumasi Metropolis of Ghana. African Journal of Agricultural Research, 11, 1608-1616. https://doi.org/10.5897/AJAR2016.10907

United Nations (UN), Department of Economic and Social Affairs, Population Division (2019). World Population Prospects 2019: Highlights (ST/ESA/SER.A/423) (46 p). United Nations.

Wedepohl, K. H. (1995). The Composition of the Continental Crust. Geochimica et Cosmochimica Acta, 59, 1217-1232. https://doi.org/10.1016/0016-7037(95)00038-2

Yobouet, Y. A., Adouby, K., Trokourey, A., \& Yao, B. (2010). Cadmium, Copper, Lead and Zinc Speciation in Contaminated Soils. International Journal of Engineering Science and Technology, 2, 802-812. 